ReLATO DE CASO: Paciente feminina, 46 anos, natural e procedente de São Paulo, procurou o dermatologista para a realização de procedimento estético de preenchimento dos sulcos naso-genianos. À pal pação, notouse pequena placa subcutânea endurecida no sulco naso-geniano direito. Realizou-se exame histopatológico da lesão, com as hipóteses de dermatofibroma, fibroma e dermatofibrossarcoma. 0 exame microscópico revelou proliferação neoplásica de células fusiformes com atipias nucleares e infiltração do tecido subcutâneo, derme profunda e reticular. A ultrassonografia de subcutâneo evidenciou imagens nodulares sólidas com até $3 \mathrm{~mm}$ de diâmetro, enquanto a ressonância magnética demonstrou espessamento difuso e homogêneo da pele na região malar e no sulco naso-geniano direito. O perfil imunohistoquímico positivo para CD34 e negativo para os demais antígenos foi compatível com dermatofibrossarcoma protuberans. A paciente foi submetida a cirurgia micrográfica de Mohs, sen do que a ressecção completa foi atingida após cinco fases cirúrgicas. Havia comprometimento profundo até o tecido músculo-esquelético Foi realizada reconstrução conjunta com a equipe de cirurgia plástica. A paciente está em seguimento há 12 meses sem sinais de recidiva.

Dıscussão: A cirurgia micrográfica de Mohs é tratamento de escolha para dermatofibrossarcoma, por promover alta incidência de cura e máxima conservação tecidual, já que este apresenta significativo potencial para recorrências (a taxa de recorrência é de $2,4 \%$ na cirurgia micrográfica de Mohs, comparada com taxa de recorrência de $11 \%$ para excisão cirúrgica local com margens de $3 \mathrm{~cm}$ ). Trata-se de tumor responsivo a radioterapia, como tratamento adjuvante a ressecção cirúrgica se houver margens comprometidas. Imatinib, um receptor de proteínas tirosina-quinase, pode ser uma alternativa de tratamento para tumores de difícil ressecção ou ainda como adjuvante cirúrgico.

\title{
DEPARTAMENTO DE COSMIATRIA DERMATOLÓGICA
}

\section{P096 Polifenóis de alcachofra: irresponsabilidade e risco!}

\author{
AUTORES: Santos AJC, Castro ACM, Prado LCG, Chaul A, Castro LCM. \\ INSTITUIÇÃO: Serviço de Dermatologia do Hospital das Clínicas - Universidade Federal de Goiás - Goiânia, GO.
}

INTRODUÇÃo: Nos últimos anos, vêm surgindo produtos que prometem resultados fáceis e rápidos em relação à aparência física. A busca do imediatismo aliada ao desconhecimento, e a compulsão para melhorar o corpo, está levando pessoas a cometer extremismos preocupantes. Assim, ao surgir um novo "milagre estético", não se leva em conta o rigor científico e a novidade passa a ser rapidamente absorvida, sem receio de possíveis efeitos deletérios. Um dos exemplos mais recentes são os Polifenóis de Alcachofra, recentemente proibidos pela ANVISA. No entanto, ainda continuam sendo utilizados irresponsavelmente.

Caso Cúnico: Relatamos o caso da paciente L.A.P., 27 anos, procedente de Goiânia, GO, que nos procurou quatro dias após se submeter à aplicação de Polifenóis de Alcachofra por um instrutor de academia da cidade. Apresentava, na região abdominal e flancos, abscessos flutuantes, volumosos e dolorosos que surgiram nos locais de aplicação dois dias após o procedimento. Foi realizada a drenagem das lesões e prescrito antimicrobiano adequado (Cefadroxil $1 \mathrm{~g}, \mathrm{VO}, 12 / 12 \mathrm{~h}$ ). Paciente evoluiu com regressão da infecção e formação de cicatrizes inestéticas inerentes ao processo de reparação tecidual por segunda intenção, necessária no caso.

Dıscussão: A literatura é escassa em se tratando dessa substância. Publicações científicas trazem alguns relatos pouco convincentes sobre propriedades antioxidantes e preventivas de acidentes cardiovasculares após sua ingestão oral. Não existem citações médicas sobre o seu uso em injeções subcutâneas, que, portanto, não devem ser utilizadas até que novos estudos comprovem sua eficácia e segurança.

Motıvo DA APRESENTAÇÃo: 0 caso apresentado é um exemplo claro da irresponsabilidade e do perigo do uso de substâncias utilizadas de maneira inescrupulosa e sem respaldo dos órgãos reguladores. Tem como objetivo maior alertar os colegas e autoridades competentes.

\section{P097 Micobacteriose atípica associada à mesoterapia com polifenóis de alcachofra}

\author{
AUTORES: Carneiro FO, Souza BA, Amorim CJD. \\ INSTITUIÇÃO: Serviço de dermatologia da Universidade do Estado do Pará - Belém, PA.
}


INTRODUÇÃO: As micobacterioses atípicas constituem um grupo de doenças causadas por micobactérias com características bem definidas do ponto de vista bioquímico, imunológico e patogênico sendo o Mycobacterium abscessus e o Mycobacterium chelonae duas espécies de crescimento rápido frequentemente associado a surtos epidêmicos al guns destes já descritos relacionados a medicações. Os autores relatam caso de micobacteriose atípica associada a mesoterapia com polifenóis de alcachofra.

Relato do Caso: C.T.B., 49 anos, sexo feminino, casada. Paciente refere que cerca de 15 dias após a realização de mesoterapia com polifenóis de alcachofra notou o surgimento no local das infiltrações de nódulos dolorosos que posteriormente se tornaram eritematosos, flutuantes e fistulizaram drenando secreção purulenta de odor fétido. Fez uso de antibióticos tó picos sem melhora do quadro. Ao exame foram observados nódulos eritematosos múltiplos, de consistência endurecida, limites imprecisos, alguns com fístulas drenando secreção purulenta localizados em terço superior das coxas, flanco direito e esquerdo. Os exames complementares realizados foram: Pesquisa de BAAR: positiva Cultura para micobatéria com identificação por PCRrestrição enzimática: isolamento de Mycobacterium abscessus II. 0 tratamento foi inicialmente antibioticoterapia com a claritromicina, porém como a resposta não foi satisfatória associou-se a ciprofloxacina. Após seis meses de tratamento apresenta cicatrização de algumas lesões porém outras ainda drenam secreção.

Dıscussão: Os surtos epidêmicos de micobacteriose atípica são em geral relacionados a micobactérias de crescimento rápido entre as quais se encontra o Mycobacterium abscessus. Tais surtos ocorrem mais freqüentemente associados à contaminação de equipamento hospitalar em virtude da presença desses patógenos na água e sua resistência aos desinfetantes habituais. Existem al guns relatos na literatura de contaminação de medicamentos. No caso em estudo a infecção ocorreu após mesoterapia com polifenóis de alcachofra, no entanto estudos bacteriológicos da amostra da alcachofra não demonstraram a presença do patógeno, levando a outras hipóteses de contaminação que ainda estão sendo investigadas.

ConclusÃo: Trata-se de um caso de micobacteriose atípica associada a injeções com polifenóis de alcahofra causada pelo Mycobacterium abscessus, sendo a origem da contaminação ainda não esclarecida.

Motivo dA APRESENTAÇÃO: Demonstrativo.

\title{
DEPARTAMENTO DE DOENCAS BOLHOSAS
}

\section{P098 Hiperceratose epidermolítica em mosaico}

\author{
AUTORES: Passos TV, Barbosa FN, Gonçalves VP, Pereira LB, Gontijo GT. \\ INSTITUIÇÃO: Serviço de Dermatologia do Hospital das Clínicas - UFMG - Belo Horizonte, MG
}

\begin{abstract}
INTRODUÇÃO: A hiperceratose epidermolítica ou eritrodermia ictiosiforme congênita bolhosa é uma rara desordem autossômica dominante da queratinização da pele. Possui prevalência mundial estimada de 1/200.000 habitantes. Cerca de $50 \%$ dos casos ocorrem esporadicamente e representam mutações novas. A forma clínica de hiperceratose epidermolítica em mosaico é caracterizada por faixas de hiperceratose uni ou bilaterais que seguem as linhas de Blaschko. Deve-se à mutação somática pós-zigótica nos genes KRT1 e KRT10.

Relato do CASO: P.L.M.C., masculino, faiodérmico, 3 anos, apresentava conforme relato materno eritrodermia ao nascimento. A partir de 2 meses de vida iniciou quadro de placas verrucosas hipercrômicas de distribuição linear, seguindo as linhas de Blaschko, nas nádegas e membros inferiores com disseminação para restante do corpo, poupando face. Sem relato de bolhas prévias e casos semelhantes na família. Realizado cariótipo: 46 XY. 0 exame histopatológico mostrou alterações típicas de hiperceratose epidermlolítica.

Discussão: Trata-se de um caso ilustrativo de uma forma rara de hiperceratose epidermolítica, com lesões exuberantes e padrão peculiar de distribuição pelo tegumento. Como as mutações podem atingir células gonadais, a doença pode ser transmitida para os descendentes do paciente acometido, com acometimento generalizado. Motivo da APRESENTAÇão: Raridade do caso.
\end{abstract}

\section{PO 99 Epidermólise bolhosa distrófica recessiva associada a albinismo: uma raridade}

\author{
AUTORES: Oliveira LML, Suehara LY, Muller H, Helene SM, Soutto Mayor S. \\ INSTITUIÇÃO: Clínica de Dermatologia da Santa Casa de São Paulo, SP
}

